\title{
WoW! Writing on Wax in Ancient Mesopotamia and Today: Questions and Results from an Interdisciplinary Project
}

\author{
Katja Weirauch and Michele Cammarosano
}

\begin{abstract}
By dispensing with the need for ink, while simultaneously providing a writing surface that retains plasticity over time, for four millennia wax boards represented the precursors of modern "smart tablets," and are therefore one of the most relevant media in human history. They consist of one or more 'leaves' provided with a recessed frame that holds a beeswax-based mixture on which marks can be scratched or impressed. Today, wax boards are no longer used in everyday life; nevertheless, they provide new and unexpected opportunities for extracurricular learning. This chapter discusses the earliest history of wax boards, as attested in the cuneiform cultures of the Ancient Near East. It compares the boards from this period with those from Classical antiquity and the Middle Ages and subsequently focuses on a cross-disciplinary pedagogical concept for sixth grade classes. It integrates history and chemistry learning by involving the schoolchildren in the "making of science."
\end{abstract}

\section{Keywords}

wax boards - cuneiform writing - Ancient Near East - chemistry didactics - history didactics

The earliest references to the use of wax boards date from the third millennium BC E. From a structural and functional point of view, wax diptychs can be truly considered as proto-codices, i.e. the earliest form of the modern book. ${ }^{1}$

1 See most recently Georgios Boudalis, The Codex and Crafts in Late Antiquity (New York: Bard Graduate Center, 2018), esp. p. 9 with fn. 21. The doubts expressed e.g. by John A. Szirmai,

(C) KATJA WEIRAUCH AND MICHELE CAMMAROSANO, 2021 | DOI:10.1163/9789004444805_003 
Used without interruption for more than three millennia for a variety of scripts in a number of different cultures, wax boards represent the longest-lived writing medium in human history. In the following discussion, we will focus on the earliest history of this medium as attested in the cuneiform cultures of the Ancient Near East, and on what those ancient times can teach us and today's schoolchildren. In doing so, we will embark on a fascinating journey at the intersection of philology, chemistry, and archaeology.

G. Boudalis made a number of observations in his brilliant study on the early history of the codex that are remarkably applicable to the reconstruction of the technology of ancient wax boards:

The evidence for reconstructing the history of the Eastern Mediterranean tradition can be separated into three types: physical, iconographical, and literary. Inevitably, evidence for each is fragmentary, especially the first, which is our primary source of information; both iconographical and literary evidence, however, can at times be surprisingly accurate and helpful. [...] Iconographical evidence, if properly and consistently studied along with physical evidence, can help fill the many gaps related to the format and making of the book in late antiquity. [...] The main problem with exploiting iconographical evidence is that unless we have related physical evidence to which to compare it, we are often left with an image that we cannot quite decipher. Nevertheless, even when there are features we do not understand, they are often consistently represented in different works of art that are not connected in any apparent way, which suggests that they reflect the reality of the codex at the time, even if that reality remains unclear. ${ }^{2}$

Given the almost total absence of physical evidence, the lack of ancient treatises, and the role played by potentially dangerous substances, the investigation of the early technology of wax boards configures a sort of mission impossible that can only be addressed by a truly interdisciplinary approach.

The Archaeology of Medieval Bookbinding (Hampshire: Aldershot et al., 1999), p. 3 with fn. 1 seem to originate from a misinterpretation of Neo-Hittite reliefs, see the discussion in Michele Cammarosano, Katja Weirauch, Feline Maruhn, Gert Jendritzki, P. Kohl, "They Wrote on Wax. Wax Boards in the Ancient Near East," Mesopotamia, 2019, LIV:121-180, pp. 133-134 with fn. 126

2 Boudalis, Codex and Crafts (cit. note 1), pp. 15-16. We are indebted to Robert Fuchs for bringing this work to our attention. On the relevance of images for the reconstruction of material culture see, among others, Peter Burke, Eyewitnessing. The uses of images as historical evidence (London: Reaktion Books, 2001), pp. 81-102. 
Interdisciplinarity is a fashionable word today, but it is easier said than done. For any researcher, keeping track of the developments within one's own field of expertise is a daily challenge, let alone going beyond it. That said, sometimes the most interesting insights arise precisely when distant disciplines meet. With its research foci in Biology and Chemistry as well as in Ancient Near Eastern Studies, the University of Würzburg provided ideal conditions for such an endeavour. This paper introduces some scientific and pedagogical products emerging from cooperation between the departments of Ancient Near Eastern Studies and Chemistry Teaching, and part of the results of the collaborative project "WoW! Writing on Wax."

\section{$2 \quad$ Writing on Wax}

Wax boards are the forerunners to paper and the graphite pencil, which first appeared in the 16th century, and today's "smart tablets." From a functional perspective, these media share a fundamental characteristic: they all allow (1) writing without ink, and (2) the erasing and re-inscribing of written text $\mathrm{ad}$ libitum. In other words, they are all excellent technology for contexts requiring frequent correction of or addition to texts, especially if working outdoors. In the case of wax boards, this is achieved by using a stylus to scratch (or impress) marks in a layer of beeswax, most commonly mixed with a mineral pigment (and sometimes further additives) in order to optimize its mechanical and optical properties. The marks can be erased simply by passing a spatula or a

3 For a detailed discussion of the facts summarized in sections 2 to 5 of the present paper see Cammarosano et al., They Wrote on Wax (cit. note 1). It would not have been possible to carry out our project without the support and help of so many colleagues, students, and friends from various fields. We are particularly grateful to Robert Fuchs, Gert Jendritzki, Doris Oltrogge and Heinrich Piening for their invaluable help on a number of crucial issues related to the writing technology of wax boards and for sharing their unpublished research results with us. We are also indebted to Lutz Martin for granting us access to the collections of the Vorderasiatisches Museum in Berlin, to Astrid Nunn and Jürgen Tautz for help and advice in the earlier stages of the project, and to Jochen Griesbach, Geraldina Rozzi, Daniel Schwemer and Miron Sevastre for their contribution to the Cuneiform Lab in December 2016. Through her excellent thesis "Altorientalische Wachstafeln. Alte Medien neu erforscht" and her enthusiastic engagement in the project, Feline Maruhn has contributed much more to this chapter than is explicitly acknowledged here. We are very grateful to Matteo Martelli and Lucia Raggetti for the opportunity to present the project results at the workshop Traces of Ink and for the wonderful hospitality in Bologna in July 2018. Financial support from the Universitätsbund Würzburg (AZ 18-33) and from the chairs of Altorientalistik (Daniel Schwemer) and Didaktik der Chemie (Ekkehard Geidel) of the University of Würzburg is gratefully acknowledged. 
globular tip over them, thereby allowing for immediate re-inscription of the surface. It is no coincidence, therefore, that, throughout history, wax boards and paper and pencil have been the privileged medium in the context of, in particular, school, bureaucracy, commerce, and the process of literary creation precisely the contexts where tablet computers are most used today (fig. 1.1c). ${ }^{4}$

There is much evidence to illustrate such circumstances, some of which is exemplified in figures 1.1 and 1.2. The Greeks and Romans made extensive use of wax boards at school, as documented by textual and iconographic sources as well as by a great number of archaeological finds, mostly from Egypt. The Romans used wax boards not only for ephemeral records, but also for legal texts, such as contracts, meant to be preserved for a longer period. A remarkable number of such documents has been recovered in Pompeii and the surrounding area, mostly consisting of sealed, multi-page board books (fig. $1.2 \mathrm{~b}-\mathrm{c}$ ). ${ }^{5}$

As mentioned, historically, wax boards have played a major role in the process of literary creation, as is immediately evident when one reads the poems of Propertius, Ovid and Martial, the Institutio oratoria by Quintilian, or Medieval anecdotal literature. Indeed, they allow the author to take notes when and where he wants - the depiction of the muse Calliope holding a wax diptych, from Triclinium A of the Inn of the Sulpicii in Murecine (fig. 1.2a), suggests that this was also true for supernatural beings. ${ }^{6}$ An illumination from a manuscript dating ca. 1380 exemplifies the peculiar features of wax boards and

4 The image in fig. 1.1c is taken from an online advertisement for the Apple iPad.

5 Fig. 1.2b shows a reconstruction of one of the triptychs from the house of L. Caecilius Jucundus in Pompeii (from August Mau, Pompeii. Its Life and Art (New York: MacMillan, 1899), pp. 490-91), and G. Boudalis' reconstruction of a Roman polyptych based on a wall painting in Pompeii (from Boudalis, Codex and Crafts (cit. note 1), p. 25 fig. 11a, kindly provided by the author). On Greek and Roman wax boards, see Giuseppe Camodeca, "Gli archivi privati di tabulae ceratae e di papiri documentari a Pompei ed Ercolano: case, ambienti e modalità di conservazione," Vesuviana: An international journal of archaeological and historical studies on Pompei and Herculaneum, 2009, 1:17-42; Benjamin Hartmann, "Die hölzernen Schreibtafeln im Imperium Romanum - ein Inventar," in Lesen und Schreiben in den Römischen Provinzen: Schriftliche Kommunikation im Alltagsleben, edited by Markus Scholz, Marietta Horster (Mainz: Romisch-Germanisches Zentralmuseum, 2015), pp. 43-58; P. Tomlin, Roman London's First Voices: Writing tablets from the Bloomberg excavations, 2010-14 (London: MOLA Museum of London Archeology, 2016); Paola Degni, Usi delle tavolette lignee e cerate nel mondo greco e romano (Messina: Hoepli, 1998); William Brashear, Francisca A.J. Hoogendijk, "Corpus Tabularum Lignearum Ceratarumque Aegyptiarum," Enchoria, 1990, 17:21-54; Elizabeth A. Meyer, "Writing Paraphernalia, Tablets, and Muses in Campanian Wall Painting," American Journal of Archaeology, 2009, 113:569-597; Boudalis, Codex and Crafts (cit. note 1), pp. 21-34.

6 Detail from Mitis Sarni opes, edited by Antonio De Simone, Salvatore C. Nappo (Napoli: Denaro Libri, 200o), p. 37. 
their interplay with other media (fig. 1.1a). It shows the Flemish mystic Jan van Ruusbroec (1293-1381) writing down notes on a wax board in a forest, inspired by the Holy Spirit. These notes were later copied onto parchment upon his return to the monastery. ${ }^{7}$ This situation was effectively summarized by Richard and Mary Rouse when they observed that "as a support for the written word, wax tablets had a longer uninterrupted association with literate Western civilization than either parchment or paper, and a more intimate relationship with

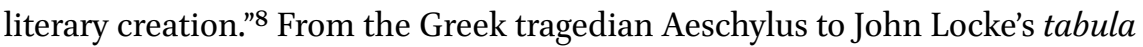
rasa and beyond, passing through Plato, Aristotle, the Stoics and many others, wax boards have also been used as a powerful metaphor for the human mind. Indeed, Sigmund Freud was inspired by a special kind of this device when he wrote his essay on human memory entitled "Notiz über den Wunderblock."

A number of extant examples of wax boards demonstrate the key role they have also played in the fields of education and administration. ${ }^{9}$ An illumination, dating from ca. 1312, provides an example for both contexts (fig. 1.1b). It depicts the name of John the Baptist being inscribed on a wax diptych on the occasion of his circumcision. Below this is a school scene, featuring a wax board with a handle (tabula ansata)..$^{10}$ The National Gallery in London also has a painting, the Pietà, probably from the workshop of Rogier van der Weyden, which features a priest with a wax board tucked into his belt (fig. 1.2e). ${ }^{11}$ This figure can be seen as a modern counterpart to the Mesopotamian incantation

7 Detail from the ms. Brussel кв 19.295-97, fol. 2v. (ca. 1380), public domain.

8 Richard H. Rouse, Mary A. Rouse, "The Vocabulary of Wax Tablets," in Vocabulaire du livre et de l'écriture au moyen âge: Actes de la table ronde, Paris 24-26 septembre 1987, edited by Olga Weijers (Turnhout: Brepols, 1989), pp. 220-230, p. 220.

9 On wax tablets in the Middle Ages and Modern Age, see Elisabeth Lalou, Les Tablettes à écrire de l'Antiquité à l'Époque moderne. Actes du colloque international du CNRS, Paris, Institut de France, 10-11 octobre 1990, Bibliologia 12 (Turnhout: Brepols, 1992); Reinhard Büll, Das große Buch vom Wachs. Geschichte Kultur Technik (München: Callway, 1977), pp. 785-894; Peter Gerlach, "Ein Lüneburger Wachstafelbuch aus dem 14. Jahrhundert," Lüneburger Blätter, 1965, 15/16:21-70; Kristina Krüger, "Schreibgriffel und Wachstafeln als Zeugnisse von Schriftlichkeit im Mittelalter," in Text als Realie, edited by Karl Brunner, Garhard Jaritz (Wien: Verlag Österreichische Akademie der Wissenschaften, 2003), pp. 229-61. Fig. 1.2d shows a waxed board-book from a monastery in or around Nuremberg, with notes and financial records (Staatsbibliothek Bamberg Msc.Var.15 [urn:nbn:de:bvb:22-dtl-ooooo17849]), dating to the 16th century CE.

10 Zürich, Schweizerisches Nationalmuseum, LM 26117, f. 179v - Gradual from St. Katharinenthal (Thurgau) (https://www.e-codices.ch/en/list/one/snm/LMo26117).

11 (c) The National Gallery, London 2019, image no. NG6265. This kind of "pocket" wax board with annexed stylus was common in the Middle Ages, see e.g. Büll, Wachs (cit. note 9), p. 849 Fig. 629 . 
a

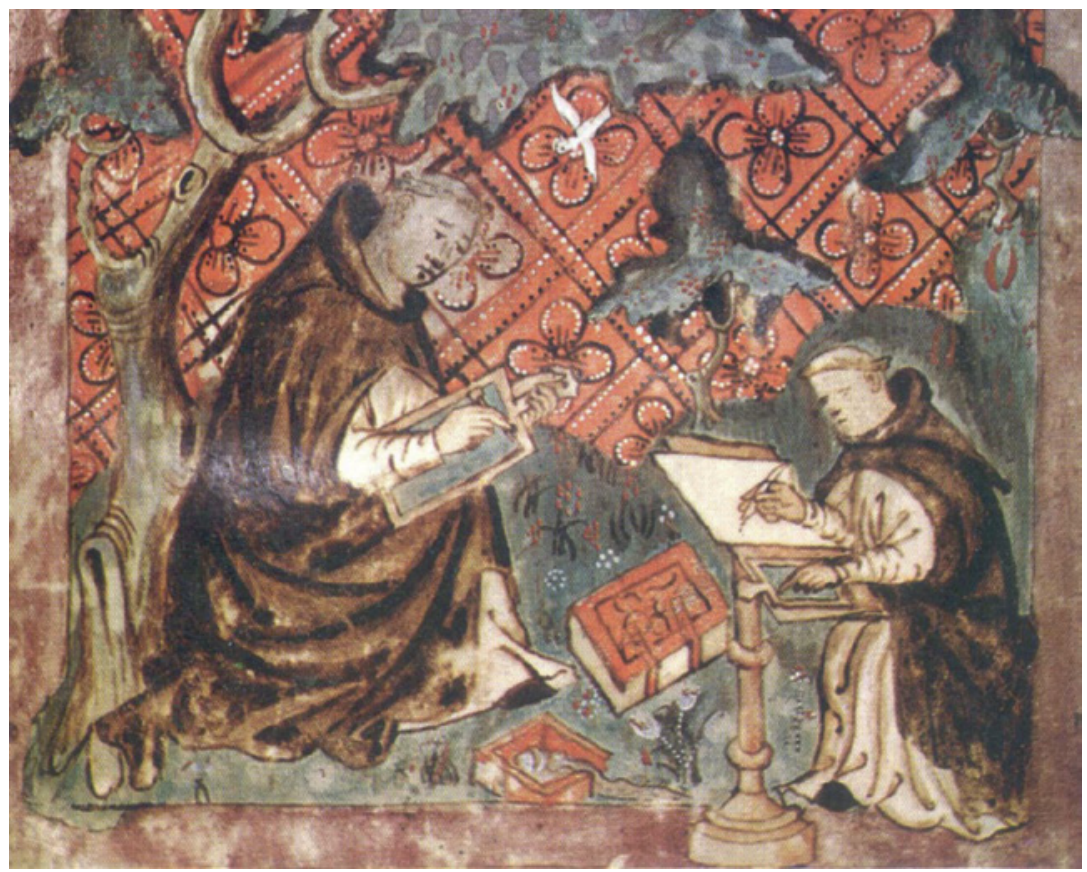

b
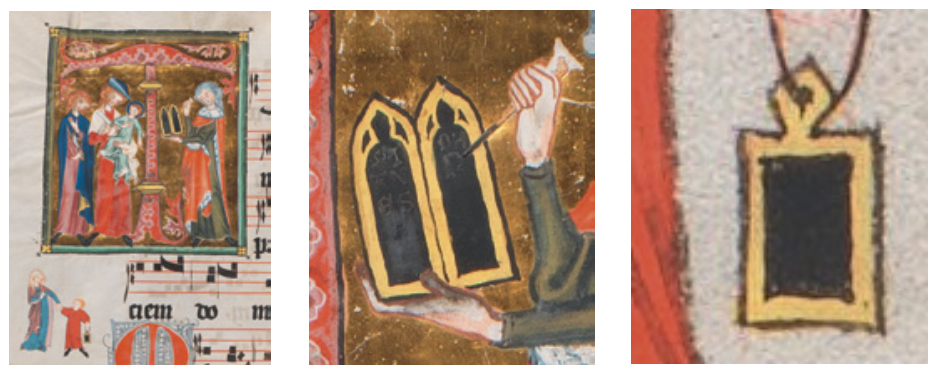

c

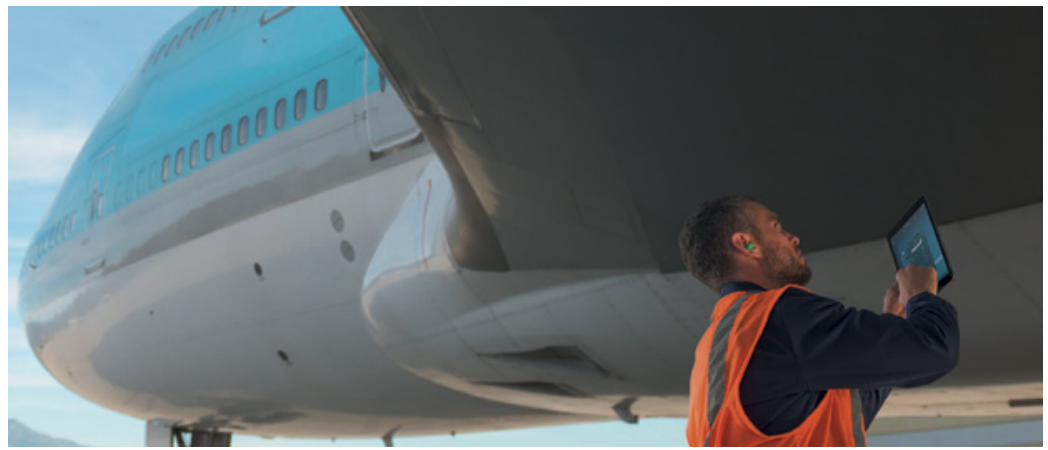

FIGURE 1.1 a) The mystic Jan van Ruusbroec (1293-1381) writing on a wax board. b) 14th-century illumination depicting a wax diptych and a tabula ansata. c) Modern tablet computer in context 

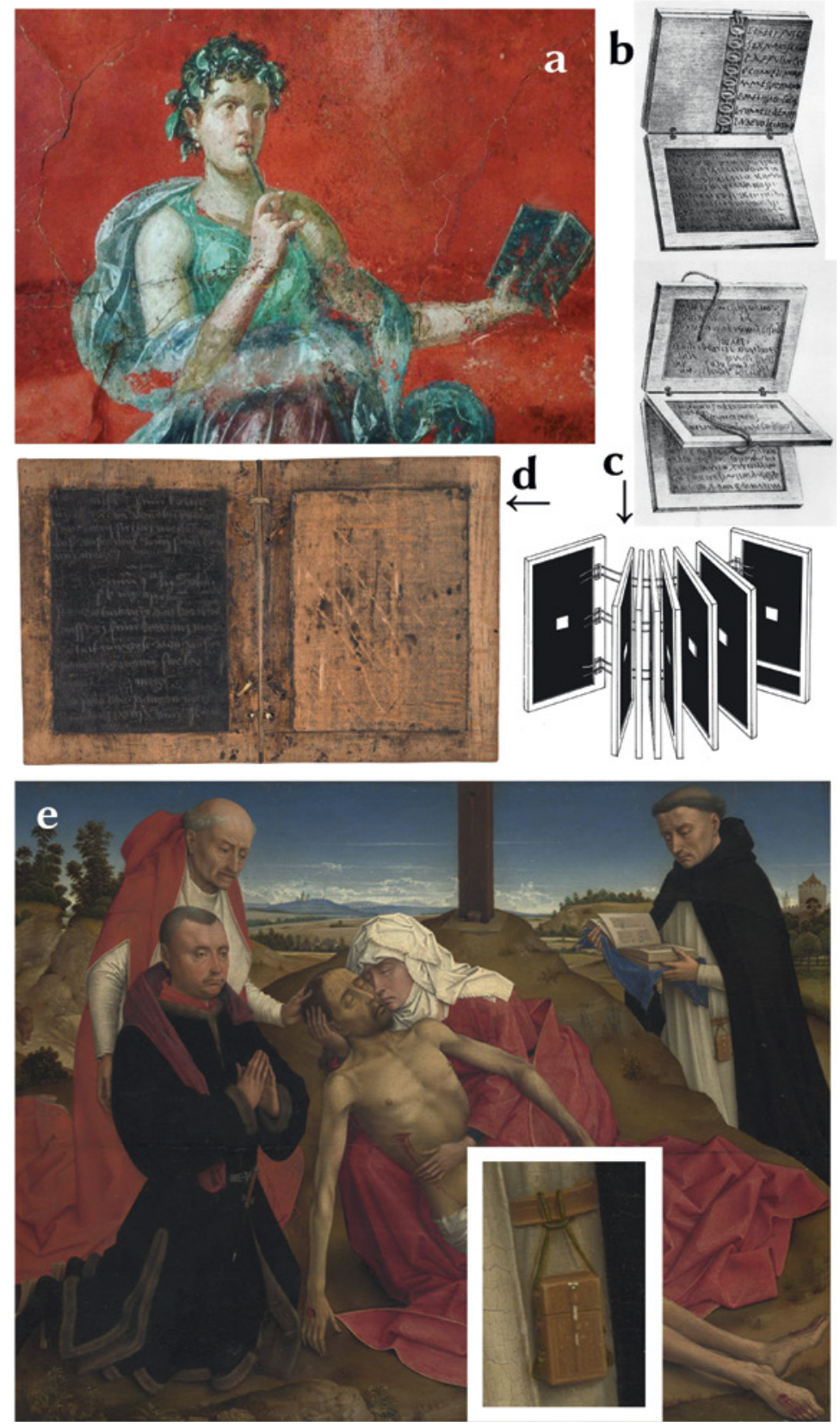

FIGURE 1.2 a) The Muse Calliope holding a wax diptych, from a Pompeii fresco. $b-c)$ Reconstruction of a Roman wax board and of a multi-page board book. d) 16th century; wax board from a German monastery. e) A Pietà from the workshop of Rogier van der Weyden (15th cent.) depicting a priest with a wax board tucked in his belt 
priest "carrying [his] writing board," mentioned in the "Poem of the Righteous Sufferer," a composition dating from the late second millennium вСЕ. ${ }^{12}$

\section{$3 \quad$ Colour Matters}

In both Classical times and the Middle Ages and, moreover, in modern Europe, the wax layer of most wax boards was black. The reason for this is that in those times beeswax was normally mixed with charcoal or soot in order to improve the plasticity of the paste. Since the letters were scratched into the wax layer with a pointed stylus, they were of the same colour as the black background, with the result that the legibility of such a board was much poorer than that of an inked piece of papyrus, parchment or, later, paper, especially in bad light conditions..$^{13}$ This is also clear from a passage by the Roman educator and rhetorician Quintilian: while recommending wax boards as the ideal medium for literary creation, he admits that text inked on parchment is more legible. ${ }^{14}$ Other authors also complained about the difficulties of reading boards made from black wax paste (Martial, for example, describes them as tristes cerae), instead praising the quality of green and red wax pastes. This attitude is reflected in the poems of Baudri, abbot of Bourgueil from 1079 to 1106, whose peculiar compositions are obsessively concerned with the process of writing itself. In the poem Ad tabulas, he writes:

Cera quidem vetus est, palearum fusca favilla, et turpat vestram cera vetus speciem.

Idcirco minor est scribenti gratia vestra

Cum velut offensum reiciat grafium.

12 Ludlul bēl nēmeqi III 41 (mašmaššum-ma naši li'um), see Wilfred G. Lambert, Babylonian Wisdom Literature (Oxford, 196o), p. 5o.

13 Only occasionally did the stylus pierce through the wax of the writing board, so that the colour of the wood underneath showed through and heightened the contrast of the sign impression.

14 Quint. Inst. Or. 10.3.31: "scribi optime ceris, in quibus facillima est ratio delendi, nisi forte visus infirmior membranarum potius usum exiget, quae ut iuvant aciem, ita crebra relatione, quoad intinguntur calami, morantur manum et cogitationis impetum frangunt" "It is best to write on wax owing to the facility which it offers for erasure, though weak sight may make it desirable to employ parchment by preference. The latter, however, although of assistance to the eye, delays the hand and interrupts the stream of thought owing to the frequency with which the pen has to be supplied with ink," quoted from Quintilian. With An English Translation. Harold Edgeworth Butler (Cambridge, MA \& London: Harvard University Press \& William Heinemann, 1922), pp. 108-109). 
Ergo pro nigra viridantem praeparo ceram,

Quo placeat scribae gratia vestra magis ... ${ }^{15}$

And in another poem, Ludendo de tabulis suis:

Sit vobis oculos viridis color ad recreandos, Sint indiruptae vincula corrigiae! ${ }^{16}$

Indeed, the existence of both green and red boards is documented by textual, iconographical, and archaeological sources. For example, the wax of one of the oldest preserved Greek boards is of a reddish colour, as is that of a number of Roman tablets recovered at Murecine, near Puteoli; ${ }^{17}$ green tablets are well attested in iconographical sources and there are a number of extant examples. ${ }^{18}$ The technology of wax boards in the Greek and Roman world can only be investigated through analysis of archaeological finds and meagre hints in literary sources. There are "recipes" available, however, for Medieval and Early Modern European specimens. The most interesting manuscripts - masterfully collected and discussed by D. Oltrogge - date from the 15th century, among them the well-known Liber illuministarum. ${ }^{19}$ By combining the evidence from these recipes with literary and iconographical sources and with the analysis published by Reinhard Büll in 1977, we get a varied picture of the

15 "As for the wax, it is old and black with grit, and this old wax disfigures your beauty. So you are less indulgent of the writer and resist his stylus as though you found it odious. Hence I am preparing green wax to replace the black, so as to make you more tolerant and friendly toward the scribe," translation after Roger Chartier, Inscription and Erasure. Literature and Written Culture from the Eleventh to the Eighteenth Century (Philadelphia, PA: University of Pennsylvania Press, 2007), p. 3.

16 "Let your colour be green, to regenerate the eye, let your straps be undisruptable!"

17 Martin West, "The Writing Tablets and Papyrus from Tomb II in Daphni," Greek and Roman Musical Studies, 2003, 1:73-92; Robert Marichal, "Les tablettes à écrire dans le monde romain," in Lalou, tablettes à écrire (cit. note 9), pp. 165-85, p. $171 \mathrm{fn} .34$.

18 Lalou, Tablettes à écrire (cit. note 9), 233-88; Büll, Wachs (cit. note 9), 808-14. One of the most famous iconographical examples of a green wax board is found in the so-called Gregorblatt (Trier, Stadtbibliothek, Hs. 171/1626; 10th cent. CE). Stimulating observations on the role of green in the context of reading and writing practices are found in Leah Knight, Reading Green in Early Modern England (Farnham et al.: Routledge, 2014), pp. 28-30.

19 D. Oltrogge, "Wachsfärbung," in Der ,Liber illuministarum' aus Kloster Tegernsee: Edition, Übersetzung und Kommentar der kunsttechnologischen Rezepte, edited by Anna Bartl, Christoph Krekel, Manfred Lautenschlager, Doris Oltrogge (Stuttgart et al.: Franz Steiner Verlag, 2005), pp. 658-62; ead., Kunsttechnologische Rezeptsammlung. Datenbank mittelalterlicher und frühneuzeitlicher kunsttechnologischer Rezepte in handschriftlicher Überlieferung (Тн Köln, Institut für Restaurierungs- und Konservierungswissenschaften, $<$ http://db.re.fh-koeln.de:220o>). 
ingredients used in the last two millennia to produce wax pastes for writing boards, including oils of various origin, resins and turpentine, dairy products, honey, ochre, charcoal, soot, verdigris, cinnabar, red lead (minium), azurite, and basic lead carbonate (white lead). ${ }^{20}$ We can assume that black paste was generally cheaper than green or red paste, since charcoal was readily available, not so verdigris or minium, the production of which also required specialized knowledge in order to be successfully mixed with beeswax.

\section{$4 \quad$ Back to Babylon}

The history of wax boards predates Greek and Roman times, reaching back to the last quarter of the third millennium вСЕ. Indeed, the Greek word for "wax

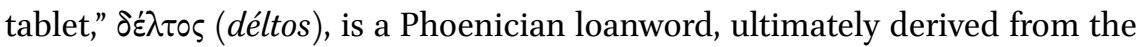
Akkadian word daltu, meaning "door," also used in ancient Mesopotamia to indicate the leaf of a waxed board book. ${ }^{21}$ The medium enjoyed growing popularity in the cuneiform cultures of Mesopotamia, Anatolia, and the Levant, with a peak in the Neo-Assyrian and Neo-Babylonian periods. In the Ancient Near East, wax boards appear to have been used primarily for writing cuneiform script and secondarily for linear scripts like Anatolian hieroglyphs and Aramaic. They were widely used for a range of different text genres, both documentary and literary.

The existence of wax boards alongside cuneiform clay tablets poses a question: what triggered the invention of wax boards in the Ancient Near East? Two aspects are problematic in this regard. Firstly, climatic factors meant that beeswax had mostly to be imported into Mesopotamia from neighboring regions. Secondly, cuneiform script is written by pressing the squared end of a stylus (mostly made of reed) into moist clay, i.e. it configures a writing technology that does not require ink and allows for the written text to be easily erased and corrected provided that the clay remains wet - precisely the features that have been defined above as the key assets of wax boards. There are two factors, however, that represent advantages of wax over clay, namely the possibility of adding text to an existing document over an extended period of time, and the ease of transport over long distances. It seems reasonable to

20 Oltrogge, Wachsfärbung (cit. note 19); ead. Rezeptsammlung (cit. note 19); Büll, Wachs (cit. note 9), pp. 796-820.

21 For evidence of wax boards in the Ancient Near East, see Cammarosano et al., They Wrote on Wax (cit. note 1). 
assume that the invention of wax boards in Mesopotamia was triggered precisely by these factors.

The most ancient archaeological find pertaining to wax boards in an Ancient Near Eastern context comes from the Uluburun shipwreck and dates from the 14th century в СE, while the boards from the Palace of Sennacherib at Nimrud (near present-day Mosul, 8th century вСЕ) represent the only example of a board with a portion of the wax layer preserved and showing traces of cuneiform signs impressed into it (fig. 1.3). According to analyses performed in the 195os in the laboratories of the British Museum, the wax layer of the Nimrud writing boards consists of beeswax compounded with ca. $25 \%$ orpiment $\left(\mathrm{As}_{2} \mathrm{~S}_{3}\right)$, a yellow mineral containing mainly arsenic sulfide, which is highly carcinogenic when swallowed or inhaled. This pigment can only be handled today in a chemical laboratory, a fact that prompted the start of the "WoW! Writing on Wax" project. Further evidence is found in cuneiform tablets from the Neo-Babylonian and Achaemenid periods (7th-6th century BCE), containing expenditure accounts related to the manufacture of wax boards. These texts not only mention wooden boards, but also regularly refer to beeswax and yellow ochre (Akkadian kalû) as the necessary raw materials, thus providing indirect evidence for the composition of the wax paste. One of these texts also mentions a certain quantity of sesame oil, yet its purpose is unclear (see below).

A bizarre circumstance further complicates the study of Ancient Near Eastern wax boards. Since wedges are produced simply by impressing a squared tip into a moist surface, the same stylus can be used to write cuneiform both on clay and wax. While not a single secure example of stylus for "cuneiform" wax boards is known, styli — both for clay and wax — are widely attested in iconographical sources, primarily as a symbol of the god Nabu in seal impressions and stelae, and within writing scenes in Neo-Assyrian wall panels. Curiously, a closer look at these sources highlights a fundamental difference in the appearance and handling of the styli connected with wax boards as compared to those used for clay tablets: while both kinds are of rectangular or trapezoidal shape, styli for wax boards display what resembles a longitudinal line or groove, whereas styli for clay tablets do not (fig. 1.4). In addition to the "groove," wax-styli sometimes also have one or more transversal bands. Particularly telling are the writing scenes found in Neo-Assyrian wall panels. Here, styli connected to writing cuneiform script on wax boards regularly show a groove on one side, and often also a horizontal band encircling them in the middle; the groove, however, is visible only when the scribes face left, otherwise only the horizontal band is shown. Interestingly, scribes with board-books are regularly shown holding the stylus upright and with index and middle fingers extended. 

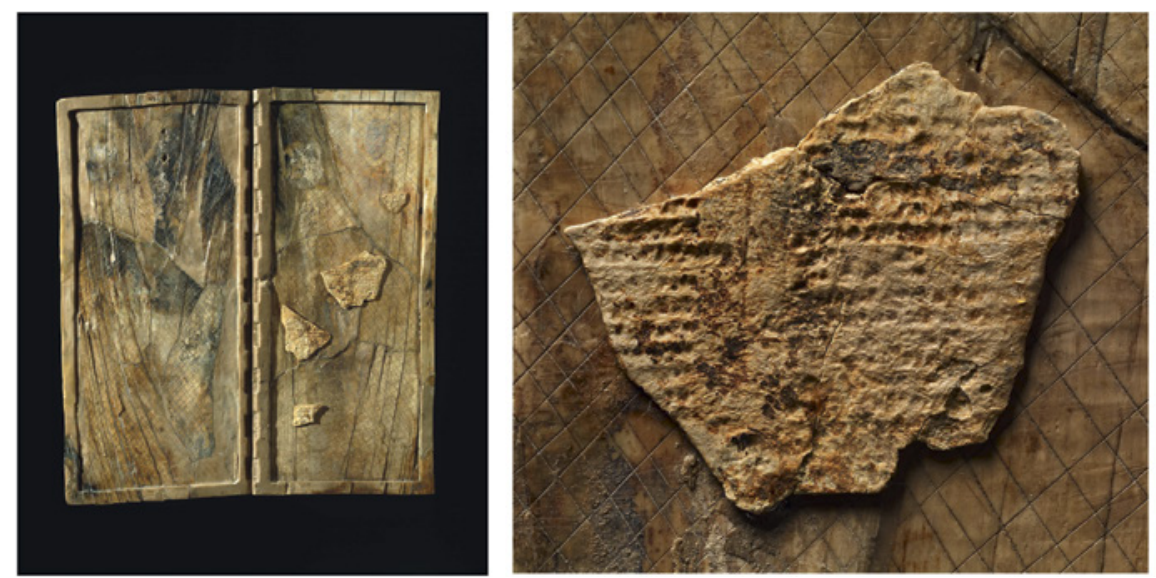

FIGURE 1.3 One of the sixteen ivory leaves hinged together in a folding board-book from Nimrud, 8th century вСЕ, and a detail of the wax layer preserving traces of cuneiform signs
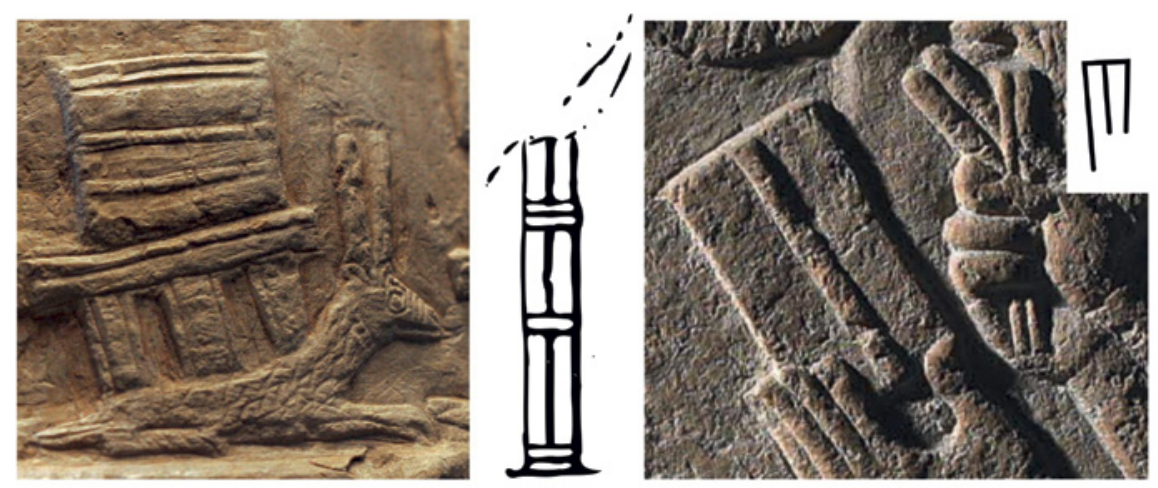

FIGURE 1.4 Examples of "grooved styli" from two Babylonian kudurru-stones (B KR nos. 40 \& 53), and from the Neo-Assyrian wall panel вм 124956

Since both the grooved and non-grooved styli are intended for cuneiform script, the difference must be related to the use of wax as opposed to clay as writing surface. What was the function of the alleged groove? In a recent article, Ursula Seidl suggested three possible options: the release of a pigment, of a substance preventing the stylus from sticking to the wax, or of a substance that softened the wax while impressing wedges. ${ }^{22}$

22 Ursula Seidl, "Assurbanipals Griffel," Zeitschrift für Assyriologie und Vorderasiatische Archäologie, 2007, 97:119-124, p. 124. 
These hypotheses are strengthened by our reinterpretation of a passage of the tablet Bм 28825, a late copy of a letter to king Assurbanipal, written on behalf of the scholars of Babylon in response to the king's request for scholarly cuneiform texts. In this letter, a reference to (date) syrup, ghee, and pressed (sesame) oil is found in fragmentary context following the mention of "seventy-two writing-boards of sissoo-wood"; most importantly, the ingredients are intended for "soaking" styli in a kettle: ${ }^{23}$

These twelve scholars have, stored in their minds like goods piled in a magazine (i.e. they know off by heart), [the entire corpus of scribal learning that] they have read and collated, and the [..., they have toiled day and] night (writing it all down); they shall not shirk, from the property of the great lord Marduk, my lord, and all the houses in [... PN] my dear brother, who [...] seventy-two writing-boards of sissoo-wood from the [house (or temple) ...] he (or I) got out [...] syrup, ghee and pressed (oil) for the kettle of their styli, to soak (them into it), ([... diš $] p u$ (làl) himètu(ì.nun. na) ù hal-șa ana ruqqi(šen) qan(gi)-țup-pí-sú-nu ana șe-pu-ú ú-še-și) and a one-litre vessel of the [...] he (or I) got out [for] their [...] and the chief scholar will exchange the tablet (credit-note?) for silver at Babylon. ${ }^{24}$

This fascinating passage suggests that styli used to write cuneiform on wax boards were occasionally soaked in a special mixture before writing. This raises a number of questions: in what proportions were these ingredients mixed together? What is meant by "soaking"? Are we to imagine a scribe repeatedly dipping the stylus in the oily mixture while writing? If so, what purpose did the substance serve? Is this reference related to the above-mentioned "groove," i.e. that the mixture referred to in the letter is precisely the substance that flow onto the writing surface while writing? Or, should we understand from this passage that the styli were to be soaked in preparation for writing?25 If so, what purpose did such a procedure serve?

23 BM 28825 obv. 17. This passage has been kindly brought to our attention by M. Frazer. The translation offered by Grant Frame, in Grant Frame, A.R. George, "The Royal Libraries of Nineveh: New Evidence for King Ashurbanipal's Tablet Collecting," Iraq, 2010, 67:265-284, p. 275, requires modification: "he (or I) got out [oil,] syrup, ghee and pressed (oil) to soak the kettle of their styli"). Frame and George have responded positively to the interpretation proposed here (pers. comm.).

24 Bм 28825 obv. 10-18, quoted after Frame and George, Royal Libraries (cit. note 23), pp. 274-75, with modifications.

25 The formulation in the text allows for both interpretations, that of "dipping" and of "soaking." 
The evidence discussed above also opens up a number of technical questions. Was the wax paste of Ancient Near Eastern boards made solely of beeswax and yellow ochre or is it possible that it involved other ingredients, as was the case later? What is the specific effect of the various ingredients on the wax paste? Are the various pastes suitable for both cuneiform and linear scripts, or do script-specific constraints emerge? What was the function of the alleged "groove" of cuneiform styli for wax and what was the corresponding writing technique? These questions can only be investigated through an interdisciplinary approach in which the study of the sources and the chemical analysis are carried out in parallel. Consequently, we created many different pastes based on the available analyses, recipes from later periods, and our own hypotheses, and tested them systematically both for cuneiform and linear script under variable environmental conditions. In the following, a summary of the main results is presented, starting with an overview of the basic ingredients involved. ${ }^{26}$

\subsection{Beeswax}

Chemically, beeswax is a hydrophobic lipophilic substance - which means that, generally, it can be mixed with oily substances but not with water. With respect to the production of writing boards, the wax must be fluid enough to be poured into the recessed frame of the boards. Since it cannot be dissolved in water, either a non-polar solvent is needed or the solid wax has to be melted. There were no satisfactory results from our tests with historically available solvents. Beeswax melts between 62 and $65{ }^{\circ} \mathrm{C}$ since it is a mixture of many components, ${ }^{27}$ most of which are long hydrocarbon chains that carry so-called functional groups. Different groups result in different chemical and physical properties in the molecules and therefore of the substances they form. Generally, beeswax can be considered as a mixture of mainly Monoesters, Hydrocarbons, Diesters and Hydroxy polyesters. ${ }^{28}$ Esters account for $70 \%$ of the composition of beeswax, with myricylpalmitate being the most abundant.

The beeswax itself is the first thing that must be considered in any attempt to decipher a possible recipe for historical wax pastes. It is assumed that the

26 For a detailed discussion of these data see Cammarosano et al., They Wrote on Wax (cit. note 1).

27 Birgit S. Fröhlich, Wachse der Honigbiene Apis mellifera carnica Pollm.: chemische und physikalische Unterschiede und deren Bedeutung für die Bienen (PhD Diss., Würzburg University, 200o).

28 H. Randall Hepburn, Christian W.W. Pirk, Orawan Duangphakdee, Honeybee Nests. Composition, Structure, Function (Berlin et al.: Springer, 2014). 
distribution of honeybees (Apis mellifera) in the Ancient Near East was largely the same as in modern times. ${ }^{29}$ Our analysis, using IR-Spectroscopy, of beeswax from extant Egyptian honeybees (Apis mellifera lamarckii) and from the Würzburg colony showed no major detectable differences, hence our decision to use current German wax for our experiments. In our tests, pure beeswax proved to be rather unsuitable for writing cuneiform due to its stickiness and translucent texture (resulting in poor legibility), thus corroborating the written sources, which hint at the addition of further ingredients.

\subsection{Pigments}

The pigments we used for our experiments were ground to a fine powder using a mortar and pestle and then added to the molten beeswax. After being stirred to form a homogeneous mixture, the fluid was poured into the recessed frame of the experimental wooden boards. Once the paste had hardened, a standardized writing test was performed by a trained specialist.

A first optically evident effect of adding pigments is the modification of the writing surface's colour, with the orpiment causing a bright yellow and the ochre producing the typical brick red or brownish yellow colour. Thus, the addition of ochre produces pastes of a colour resembling that of clay tablets and orpiment imitates the appearance of gold..$^{30}$ It is no coincidence, therefore, that the luxury ivory boards from the royal Palace of Sennacherib at Nimrud contain orpiment, whereas the Neo-Babylonian accounts only mention ochre: the latter was no doubt the standard additive used in ordinary Mesopotamian boards. Charcoal and verdigris, commonly used in the Middle Ages and in modern Europe, were also tested, producing plain black or bright turquoise pastes, respectively. As discussed above, the colour of the paste is a key factor for the legibility of cuneiform and linear scripts, since in both cases it is strongly dependent on the contrast between the writing and the background in a given light. We can apply a general observation to both types of scripts, namely that the least legible background colours are white and black, whereas sienna, green and turquoise all perform well - an observation that supports the available written sources (see above, §3). In view of the fact that high quality ochre was readily available all over ancient Mesopotamia, it seems likely that yellow ochre was the standard additive to beeswax in Ancient Near

29 Cammarosano et al., They Wrote on Wax (cit. note 1), pp. 125-129

30 An interesting comparison is provided by the various techniques used in Medieval illuminated manuscripts to imitate the colour of gold, see Doris Oltrogge, "Scriptio similis auri.' Gold und Goldähnlichkeit in der Handschriftenausstattung: Surrogat, Imitation, Materialillusion?," in Codex und Material, edited by Patrizia Carmassi, Gia Toussaint (Wiesbaden: Harrassowitz, 2018), pp. 159-178. 
Eastern wax boards, whereas charcoal may have been used in Greece and Rome, simply because it was the most widely available pigment and subsequently canonized as a standard ingredient.

Apart from the colouring, the addition of pigments to the wax paste reduces the beeswax' stickiness and increases its malleability. ${ }^{31}$ As far as ochre is concerned, two of the Neo-Babylonian cuneiform accounts mentioned above suggest a proportion of $6.6 \%$ and $10 \%$ of ochre in the wax paste, a quantity that is very close to the average amount of ochre present in the sample of wax boards analysed by Reinhard Büll. ${ }^{32}$ Our tests showed that the addition of ochre (or arsenic sulfide), ${ }^{33}$ up to an amount of ca. $40-50 \%$, generally makes the paste softer than pure beeswax and reduces its stickiness, thus meeting the basic requirements for a writing board. The proportion of either of these ingredients may vary between ca. $5 \%$ and ca. $50 \%$; pastes with more than $50 \%$ ochre become too granular and too hard, especially at low temperatures, so that the wedges can be impressed only with difficulty.

\subsection{Oil}

In the tests we conducted, adding sesame oil had the effect of making the wax more sticky and it produced a rather greasy consistency. Consequently, the pastes were not suited for writing cuneiform. However, oils are among the ingredients in modern recipes for wax board pastes, a fact which deserves further investigation.

\subsection{Resins}

Both ancient recipes and the analysis carried out by Reinhard Büll on 37 boards, dating from a period spanning from the Late Antiquity to the 18 th century $\mathrm{CE}$, attest to the occasional presence of resins (colophony and myrrh) and turpentine in the paste of wax boards. ${ }^{34}$ This is puzzling, since our tests showed that the addition of resin hardens the wax paste, thus making it rather unsuitable for writing. We submit that the addition of resin may be related to the custom of mixing beeswax with both pigments and resins in sealing practices, and in some cases may also be connected to the quality of the wax that was used at that time. ${ }^{35}$

\footnotetext{
31 If the quantity of pigment is gradually increased, the paste gets harder again.

32 Büll, Wachs (cit. note 9), pp. 808-15.

33 Importantly, arsenic sulfide serves this purpose well, also when used alone, and necessitates no additional ingredients.

34 Büll, Wachs (cit. note 9), pp. 808-14; on the use of resins see also Oltrogge, Wachsfärbung (cit. note 19), pp. 585-9o and 595-96.

For more details see Cammarosano et al., They Wrote on Wax (cit. note 1), pp. 157-158.
} 


\subsection{The Role of Physical Factors}

The temperature of the paste and the shape and physical properties of the stylus are important factors that influence writing cuneiform on wax. The effort required to impress wedges is directly proportional to the amount of pigment present in the wax paste, and inversely proportional to the temperature of the writing environment. This means that the more pigment the paste contains, the greater the pressure required to write; conversely, the higher the temperature, the easier it is to impress wedges. ${ }^{36}$ Writing cuneiform on a paste containing $50 \%$ ochre at minus $10^{\circ} \mathrm{C}$ requires a lot of pressure, whereas a paste with only $7 \%$ ochre feels very soft when writing at a room temperature of $35^{\circ} \mathrm{C}$.

\subsection{Writing Technique}

In order to investigate the hypothesis that Mesopotamian "wax styli" had a longitudinal groove, we tested various options, the most intriguing one being the idea of a "reservoir" for liquid substances that were intended to flow onto the writing surface continuously during the writing process (fig. 1.5). These substances either worked as a release agent, thus preventing the stylus from sticking to the wax surface, or they may have coloured the wedges, thus improving contrast and legibility. The latter option was not feasible, since the liquid could not properly flow along the appropriate corner of the stylus down into the wedges. That said, coloured wedges can be achieved when a larger amount of fluid containing a convenient quantity of date syrup (or other colouring substance) is used, and the surface is then wiped with a sponge (or similar), immediately after writing. While the part of the fluid that is on the surface is wiped off, the part which flowed in the wedges remains there and, after the oil has been absorbed, results in more or less red-coloured wedges, a sort of Mesopotamian counterpart to the litteraerubricatae of the Greco-Roman world (fig. 1.5). Whether such a technique was ever used in ancient Mesopotamia remains a matter of speculation.

The option of a groove to optimize the use of an oil-based release agent, of the kind referred to in the cuneiform letter BM 28825 , proved to be more conducive. Our experiments involved periodically dipping the stylus in a viscose mixture composed of sesame oil, date syrup and ghee, while writing. These experiments showed that the use of such a release agent prevents the stylus from sticking to the surface and thus damaging the shape of the wedges, a problem arising especially under specific temperature conditions and when using bone or metal styli (fig. 1.5).

$3^{6}$ This empirical conclusion applies to mixtures of beeswax and ochre (up to $50 \%$ ), and does not contradict the observation that such mixtures feel softer than pure beeswax when writing cuneiform on them. 

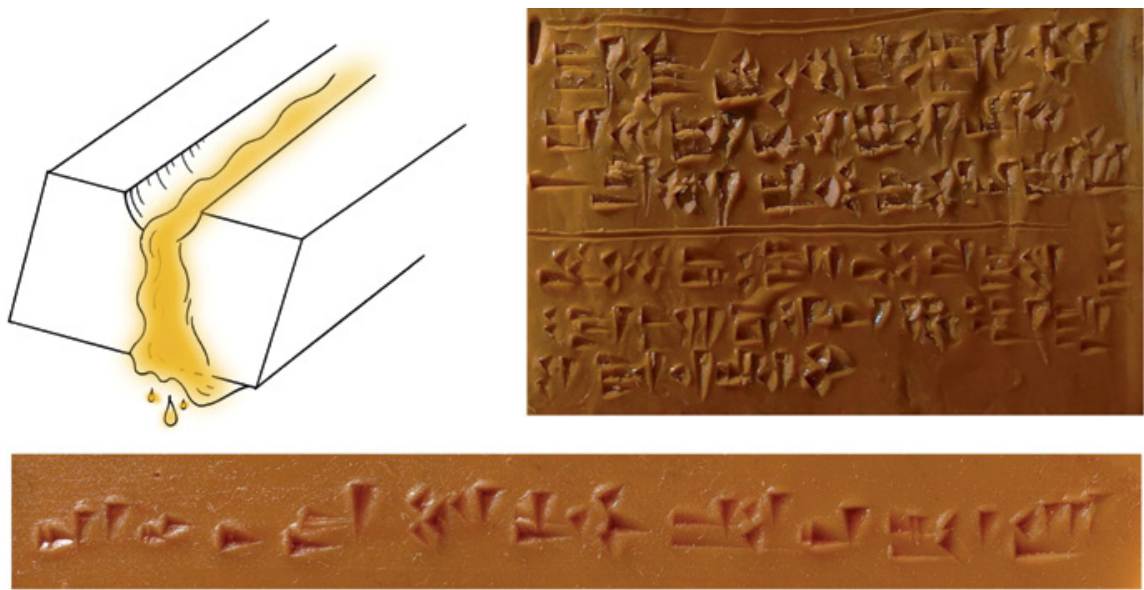

FIGURE 1.5 Schematic operation of an alleged "grooved stylus," coloured wedges achieved by means of a release agent with a high content of date syrup, and an example of the difference in the appearance of wedges obtained by means of a metal stylus without (top paragraph) and with (bottom paragraph) the use of a release agent made from sesame oil, date syrup and ghee

The use of an oil-based release agent has two drawbacks: the stylus has to be periodically dipped into it, and, unless one manages to permeate only the writing tip, it becomes slippery and greases the writer's finger. Both a proper groove cut along the main side of the stylus and a simple pattern carved on it may mitigate these drawbacks, as they function as a "reservoir" for the release agent (thanks to the effect of surface tension) and increase the grip on the stylus' shaft. Of course, the reservoir function is minimal in the case of engraved lines, maximal in the case of a proper groove. The pace at which the release agent flows onto the writing surface depends on its viscosity, hence on its components and on temperature, and is also influenced by the shape and dimensions of the groove (or lines) engraved on the stylus. These conditions seem to explain the use of ghee and syrup as components of the mixture attested in the cuneiform tablet BM 28825: while oil alone is able to attain the same desired effects, the addition of ghee and syrup gives the mixture the necessary viscosity. ${ }^{37}$ When such a fluid is used, it forms a film that is progressively

37 A set of experiments related to the composition of the release agent is presented in Feline Maruhn, Altorientalische Wachstafeln. Alte Medien neu erforscht (Zulassungsarbeit zur Ersten Staatsprüfung für das Lehramt an Gymnasien, Julius-Maximilians-Universität Würzburg, 2017), pp. 98-108. Experimental "grooved styli" of metal and bone have been manufactured with the invaluable assistance of Miron Sevastre (Martin von Wagner-Museum, University of Würzburg), to whom we express our gratitude. 
absorbed into the wax paste. Under normal temperature conditions, after a couple of days, the film is almost invisible to the eye.

The question remains of whether such a groove is really necessary for the use of a release agent. The answer is - probably not, although a groove of appropriate shape and dimensions optimizes the "reservoir" function. In the absence of a groove, the stylus must simply be dipped more frequently into the release agent. Be this as it may, how can we explain the transversal bands - sometimes one, sometimes more - that are occasionally visible on depictions of "grooved styli"? Important evidence in this regard emerged in May 2018, when we were able to examine two Neo-Assyrian ivory rods at the Vorderasiatisches Museum in Berlin. ${ }^{38}$ The two rods, which were found in a grave together with a wax diptych, show, respectively, one and two engraved lines running around the "shaft" (fig. 1.7). We propose to interpret them as writing implements, and submit that the "groove" is an iconographic motif characterizing styli used to write on wax. The motif would consist of a line engraved in the middle of the stylus, which would symbolize a (wax) diptych in profile view (fig. 1.6). Such a motif would have the advantages of simplicity and functionality: an immediate allusion to wax boards, brilliantly obtained within the spatial constraints of an elongated parallelepiped, and also improving the fingers' grip on the stylus.

Thus, we are left with two different interpretations of the "groove," one that is mainly functional (a real groove as a reservoir for a release agent); the other mainly aesthetic/iconographic (a motif alluding to a diptych). The former remains speculative, whereas the latter is supported by iconographical variants showing multiple transversal bands, a fact that cannot be reconciled with anything other than a symbolic reference to a closed diptych in profile view. However, the two interpretations are by no means mutually exclusive. At present, we can neither establish whether and when the practical and iconographical functions may have coexisted, nor whether there was a phylogenetic relation between them, i.e. whether the invention of the motif was triggered by the practice of providing wax styli with a groove or vice versa.

To conclude this section, we present an educated guess about what a brand-new cuneiform wax board may have looked like (fig. 1.7) ${ }^{39}$

38 Inv. no. va Ass 3545.3-4, see for details and discussion Cammarosano et al., They Wrote on Wax (cit. note 1), pp. 162-166. We are very grateful to Lutz Martin for granting us access to the collections of the Vorderasiatisches Museum and to Gert Jendritzki for his support during our stay in Berlin in May 2018 as well as for the stimulating discussions.

The reconstruction model of the diptych has been conceived and manufactured by Gert Jendritzki (Staatliche Museen zu Berlin, Vorderasiatisches Museum), see Gert Jendritzki, Matthias Streckfuß, Michele Cammarosano, "Technische und materialgerechte Rekonstruktion einer Elfenbein — Klapptafel aus Aššur," Mitteilungen der Deutschen 

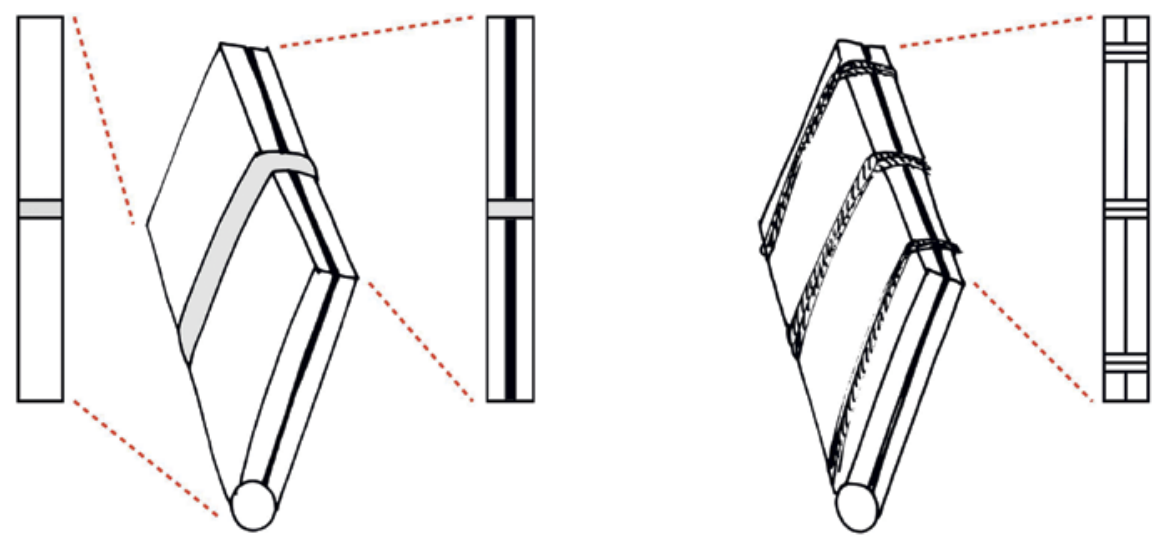

FIGURE 1.6 Schematic representation of the hypothetical gestation of the "grooved stylus" motif

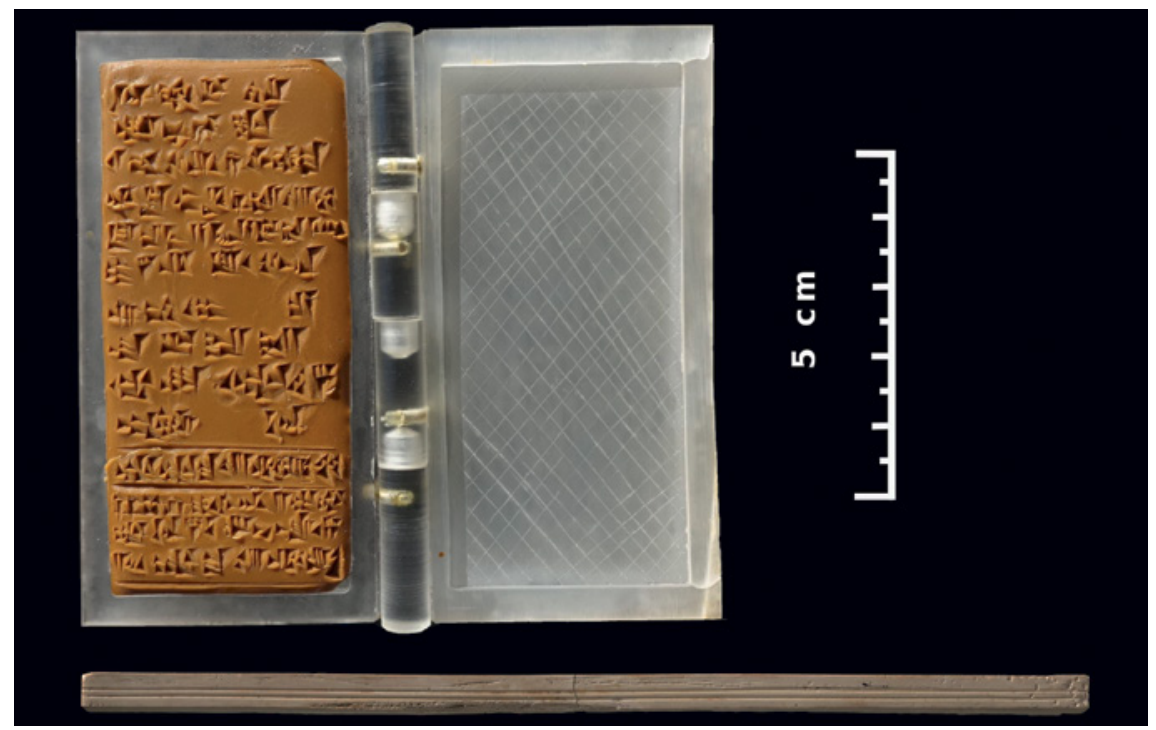

FIGURE 1.7 Top: The potency incantation LKA 95 rev. 6-11 written with a replica of the "grooved stylus" VA Ass 3545.4 on a Plexiglas reconstruction of the Neo-Assyrian diptych va Ass 3541. Bottom: The "grooved stylus" va Ass 3545.4 
As discussed above, wax boards have a long history in learning and schooling. Furthermore, one of the main aims of the "WoW! Writing on Wax" project is to communicate the research findings to the public, especially to schoolchildren, thus the idea of getting "writing on wax" back into schools is rather appealing. Since chemistry as well as history tend to be relatively unpopular subjects among pupils, an alternative approach is required. ${ }^{40}$ One pedagogical approach to increase children's interest proposes non-formal, extracurricular settings for learning. ${ }^{41}$ Museums, for example, offer the chance to explore objects that schools do not have access to. Such a direct encounter fosters a perception of authenticity that has proven to be helpful for learning. ${ }^{42}$ Another approach is to encounter facts in a way that connects them to the everyday experiences or general interests of children. This adds an individual "sense-making" to the topics discussed, which, according to constructivist learning theories, supports their memorization. ${ }^{43}$ Finally, studies show effective learning favours active doing over passive listening. ${ }^{44}$ In terms of history, this may be the exploration

Orient-Gesellschaft 151 (2019), 201-218, also available at <www.osf.io/urpuf/wiki/home/>. The wax paste is made of beeswax with $25 \%$ ochre; the text reads: "Wind blow, orchard shake, Clouds gather, droplets fall! Let my potency be (steady as) running water, Let my penis be a (taut) harpstring, Let it not slip out of her!" (LKA 95 rev. 6-11, translation after B.R. Foster, Before the Muses. An Anthology of Akkadian Literature (Bethesda, 2005), p. 100o). Jonathan Osborne, Shirley Simon, Sue Collins, "Attitudes towards Science: A review of the literature and its implications," International Journal of Science Education, 2003, 25:9, 1049-1079.

41 Katrin Engeln, Schülerlabors: authentische, aktivierende Lernumgebungen als Möglichkeit, Interesse an Naturwissenschaften und Technikzu wecken (Berlin: Logos Verlag, 2004); Fiona Affeldt, Sakari Tolppanen, Maija Aksela, Ingo Eilks, "The Potential of the Non-Formal Educational Sector for Supporting Chemistry Learning and Sustainability Education for all Students - a joint perspective from two cases in Finland and Germany," Chemistry Education Research and Practice, 2017, 18:13-25.

42 Ulrich Mayer, Peter Adamski, Klaus Bergmann (eds.), Handbuch Methoden im Geschichtsunterricht (Schwabach: Wochenschau Verlag, 2013); Jean Lave and Etienne Wenger, Situated Learning: Legitimate Peripheral Participation (Cambridge: Cambridge University Press, 2001); and Karen Malone, Every Experience Matters: An evidence-based research report on the role of learning outside the classroom for children's whole development from birth to eighteen years (Warwickshire: Face, 2008).

43 Ernst von Glasersfeld, Was heißt „Lernen" aus konstruktivistischer Sicht? in Unterricht aus konstruktivistischer Sicht - Die Welten in den Köpfen der Kinder (Neuwied: Luchterhand, 2002), and Kenneth G. Tobin, The Practice of Constructivism in Science Education (New York: AAAs Press, 1994).

44 Johanna Meixner, Klaus Müller, Angewandter Konstruktivismus - ein Handbuch für die Bildungsarbeit in Schule und Beruf (Aachen: Shaker-Verlag, 2004). 
of historical objects, materials or ways of living. Conducting experiments is the favoured method for chemistry.

Considering these findings, two pedagogical programmes were developed. On the one hand, a set of experiments was designed that can replace or complement the existing, standard experiments in school. For example, esterification and saponification are usually explained using the example of oils or fats, but may be understood just as well using the example of beeswax esters being saponified when following a historical recipe for so-called Punic Wax. Professional characterization of waxes includes the determination of acid number, ester value and saponification number. In all three cases, the method was adapted to school experiments with beeswax. In order for this to make sense for the children, each experiment answers an authentic question in the context of writing on wax in history. ${ }^{45}$ On the other hand, an extracurricular "lab day" at the Martin von Wagner-Museum in Würzburg was arranged and tested with a sixth-grade class.

\section{7}

\section{A Cuneiform Lab}

The main aim of the extracurricular programme was to inspire the sixth-graders and get them fascinated in writing on wax - and thus surreptitiously teach about life in the Ancient Near East - as well as to impart knowledge about chemical experimental competencies and the properties of common substances. ${ }^{46}$ By approaching an authentic context from two perspectives chemical and historical - a higher interconnectedness of knowledge and therefore a higher quality of learning can be achieved. Moreover, the lab provided a good opportunity to introduce schoolchildren to the riches of the Ancient Near East. ${ }^{47}$

45 Feline Maruhn, Katja Weirauch, Ekkehard Geidel, Michele Cammarosano, "Historische Wachstafeln - Alte Medien neu entdeckt," Praxis der Naturwissenschaften - Chemie in der Schule, 2017, 2:31-35.

46 A "call for applications" was launched in autumn 2016; class 6a of the Riemenschneider Gymnasium Würzburg was subsequently selected to participate in the Cuneiform Lab.

47 It must be stressed that the Ancient Near Eastern civilizations are not dealt with at all in today's German curriculum, so the children usually have no idea about that world. The situation is different in other countries, and it was different in the DDR (on which, see Hans Neumann, "Der Alte Orient in der Schule: Erfahrungen (und Perspektiven?) beim Verfassen von Geschichtslehrbüchern," Altorientalische Forschungen, 2016, 43:170188. For other stimulating pedagogical approaches to the Ancient Near East, see Sabine Böhme, "Viele Wege führen nach Babylon. Das einjährige Museum \& Schule-Projekt «Gartenzwerg trifft Nebukadnezar»," Antike Welt, 2016, 47/5:37-41; and Cécile Michel, 
Pedagogically, the first step must always be the activation and verbalization of the learners' preconceptions. At the time the Cuneiform Lab was organized, the Martin von Wagner-Museum was hosting an exhibition on the Assyrian capital Nineveh, the site of which lies on the outskirts of present-day Mosul, in northern Iraq. ${ }^{48}$ The exhibition focused on high-resolution, large format photographs of a number of scenes from the wall panels of king Sennacherib's "Palace without Rival," including those portraying scribes recording booty on wax boards. At the time of the exhibition, Mosul was sadly the scene of severe clashes between the Iraqi forces and ISIL, which were reported in the media and thereby provided an immediate access to the geographical area of interest, since most of the children had heard of the war in the Middle East. The photographs shown in the exhibition also depicted scenes from wars of that time, triggering a discussion about weapons, warfare and politics in the Ancient Near East - and today. Since there was a lot of information to master within a relatively short period of time, it was crucial to break down the contents and focus the children's interests. We therefore chose not to do a simple guided tour through the exhibition, but rather gave the children tasks to fulfil in small groups. For example, the groups were given several types of wooden swords and had to find out which one corresponded to those used by the Assyrian army, as portrayed in the wall panels (fig. 1.8). The children also discovered that the "correct" sword had a cuneiform inscription, a fact that served to introduce this kind of script.

While discussing the fascinating circumstances that led to Sennacherib's death, ${ }^{49}$ the pupils asked how we know about this 3000-year-old crime. The image of two scribes led to the conclusion that there is written evidence - namely, cuneiform tablets that survive to this day. The next phase of the Cuneiform Lab took place in the rooms of the Department for Ancient Near Eastern Studies (adjacent to the museum), where the children had the opportunity to learn the cuneiform writing system. Coming into contact with

"L'écriture cunéiforme, première écriture dans l'histoire de l'humanité. À l'école des scribes," La lettre de l'INSHS, 2013, 25:8-12.

48 The exhibition Ninive. Bilder aus Sanheribs "Palast ohnegleichen" at the Martin von Wagner-Museum of the Würzburg University (21.10.2016-19.02.2017) was organized by the Department for Ancient Near Eastern Studies of the Würzburg University in cooperation with the Centro Archeologico Ricerche e Scavi of Turin. We are most grateful to Jochen Griesbach, director of the museum, for allowing us to organize the Cuneiform Lab in the framework of the exhibition.

49 Simo Parpola, "The Murderer of Sennacherib," in Death in Mesopotamia, XXVIe Rencontre Assyriologique Internationale, edited by B. Alster (Copenhagen: Akademisk Forlag, 1980), pp. 171-182. 


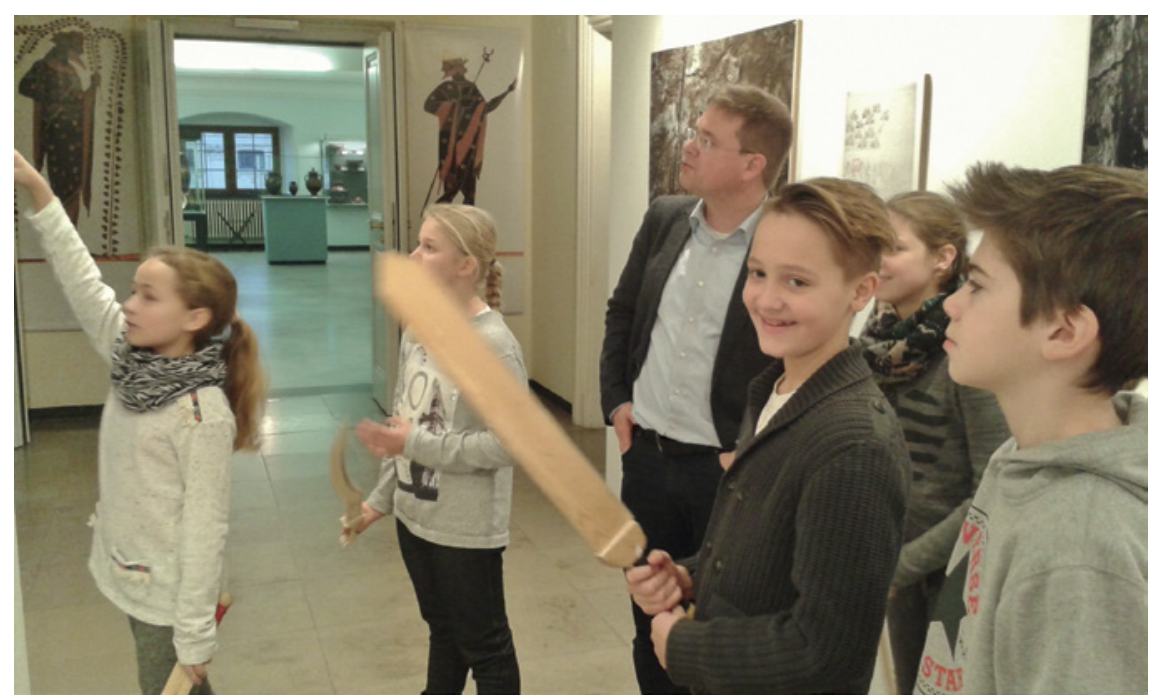

FIGURE 1.8 Assyrian swords and ancient crimes: a moment during the Cuneiform Lab at the Martin von Wagner-Museum of the University of Würzburg

real cuneiform tablets creates an immediacy and authenticity not possible to achieve in school. We were able to bridge the time gap between the Ancient Near East and today by showing the pupils examples of Babylonian school children's attempts at writing cuneiform on clay tablets. With the help of a template with Babylonian cuneiform signs, the children were then challenged to write their own name in cuneiform on clay tablets, which could be taken home afterwards (fig. 1.9).

When writing on clay, the children experienced the difficulties of the clay drying out and becoming hard. The issue of clay tablets versus wax boards was discussed in relation to the wall panel that depicts two scribes visible in the exhibition. Beeswax was introduced as the only historically available material that allowed for repeated erasing or correcting of mistakes in writing over time. The problem of not knowing the recipe for wax tablets for cuneiform writing was also presented.

Moving into the lab rooms, the source of beeswax and the biology of the honeybee were explored. Finally, the main question of the "WoW! Writing on Wax" project was presented to the children: what is the ideal recipe for a wax paste for cuneiform writing? In order to come up with a potential recipe, the children first had to become familiar with the chemical and physical properties of historically plausible ingredients. This opened them up to chemical knowledge, rather than simply "learning" chemistry for no apparent reason, which 


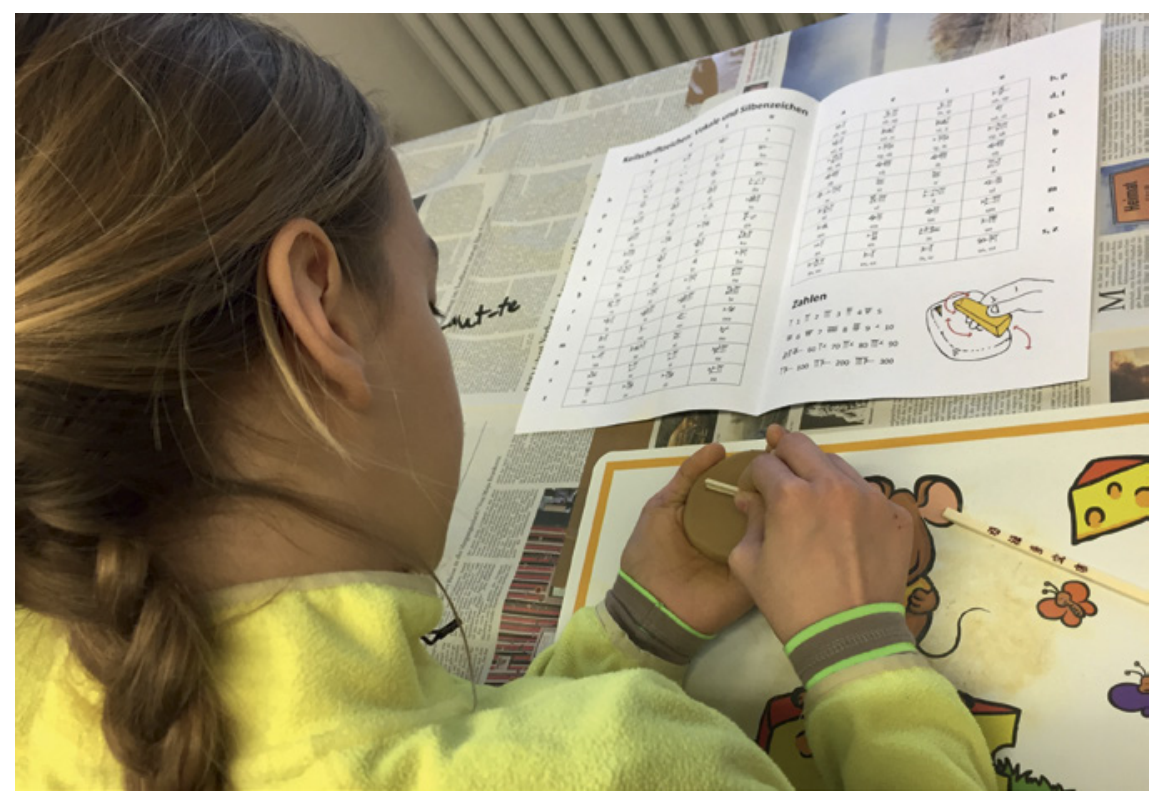

FIGURE 1.9 Learning cuneiform

schoolchildren often feel is senseless. ${ }^{50}$ They conducted preliminary experiments to explore the solubility, melting point and thermal behaviour of possible ingredients for wax pastes. Using this knowledge while working in groups, they developed and documented their "ideal" recipe for a cuneiform-oriented wax paste (fig. 1.10).

Thus, by asking the same questions that the "real" scientists were working on and, like them, trying to find a solution, dealing with historical and chemical facts made sense. Additionally, on a meta-level the children learned a lot about a pedagogical construct that researchers relate to as the "Nature of Science" (NOS). ${ }^{51}$

A wide-ranging discussion has evolved in recent decades about what the aim of science education should be and what, consequently, should be taught.

50 Helena van Vorst, Sabine Fechner, Elke Sumfleth, "Kontextmerkmale und ihr Einfluss auf das Schülerinteresse im Fach Chemie," in Inquiry-based Learning — Forschendes Lernen: Jahrestagung in Hannover 2012, Gesellschaft für Didaktik der Chemie und Physik 33, edited by Sascha Bernholt (Kiel: IPL-Verlag, 2013), pp. 311-13.

51 See e.g. N.G. Lederman, "Students' and Teachers' Conceptions of the Nature of Science: A Review of the Research," Journal of Research in Science Teaching, 1992, 29/4:331-59; N.G. Lederman, "Nature of Science: Past, Present and Future," in Handbook of Research on Science Education, edited by S. Abell, N.G. Lederman, (Mawah: Lawrence Erlbaum Associates, 2007), pp. 831-79. 

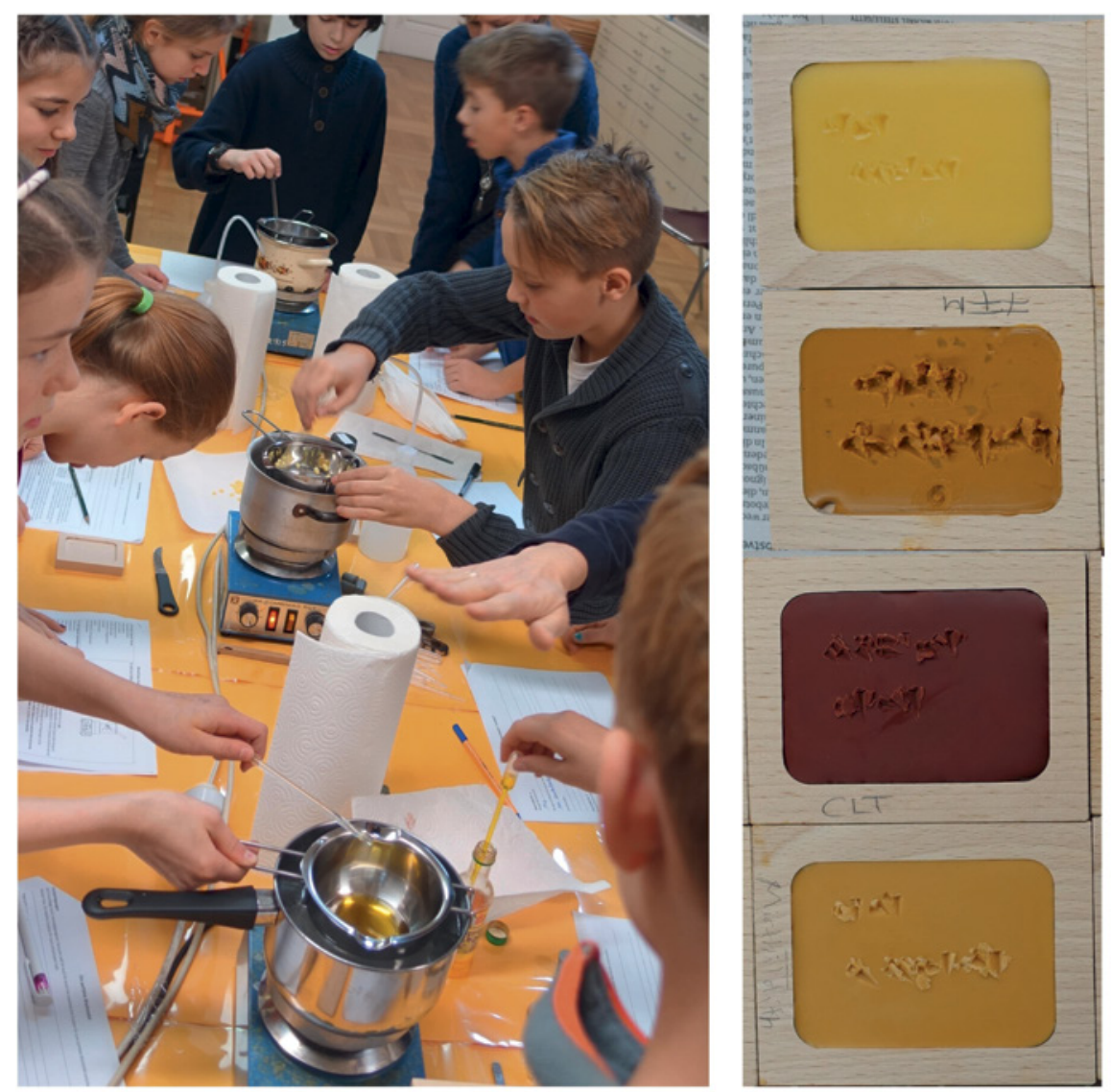

FIGURE 1.10 Mixing ingredients to obtain the ideal wax paste for cuneiform script, and a look at the results

As part of this, it was decided that every student should achieve "Scientific Literacy," enabling them to make rational decisions and become a responsible part of modern society. ${ }^{52}$ An essential part of this literacy involves understanding what the nature of scientific knowledge is (NOSK), but also how this knowledge is achieved through inquiry (NOSI). ${ }^{53}$ By acting themselves as researchers, the children experience important aspects and rules of the Nature of Science,

$5^{2}$ George E. DeBoer, "Scientific Literacy: Another Look at Its Historical and Contemporary Meanings and Its Relationship to Science Education Reform," Journal of Research in Science Teaching, 2000, 37/6:582-6o1; R.C. Laugksch, "Scientific Literacy: A Conceptual Overview," Science Education, 2002, 84/1:71-94.

53 Irene Neumann, Beyond Physics Content Knowledge - Modeling Competence Regarding Nature of Science and Nature of Scientific Knowledge (Berlin: Logos Verlag, 2011). 
such as the need for preliminary exploration of the method, the difficulties of matching hypothesis and experiment, the importance of accuracy in documentation, but also - and most importantly - the fun of discovery. At the end of our lab day, every group handed in their wax board, and a specialist tested them by inscribing them in cuneiform, so that the best recipe could be identified - and rewarded with a chocolate equivalent.

No scientific inquiry has been done on the success of this pedagogical programme in terms of motivation and learning. However, since all the children - without exception - were working enthusiastically throughout the whole four hours, we dare to conclude that it is truly worth all the work and organizational effort. ${ }^{54}$ The feedback from the three teachers involved confirmed this impression. Moreover, we proved that it is possible to successfully combine apparently distant topics, such as history and chemistry, within one pedagogical concept, resulting in powerful synergies not only for science, but for teaching as well.

\section{$8 \quad$ Conclusions}

Our search after ancient wax boards has become a fantastic journey at the intersection of archaeology, chemistry, cuneiform studies, and didactics. It is our hope that our study will shed some light on a rather forgotten writing technology that played an important role in the literacy of ancient times. Moreover, we hope that our trial will encourage others to embrace a truly interdisciplinary approach in the study of writing technologies, and to further explore ways of contaminating scientific projects with school teaching. Indeed, the main core of collaboration involved understanding each other's language and way of thinking (a process that continues to challenge us to this day), and finding ways to involve school children in the process of "making science." Their enthusiasm as well as the surprising scientific insights that arose in the course of the Cuneiform Lab have been among the greatest rewards for our efforts.

54 A report on the Cuneiform Lab is posted on the website of the Riemenschneider Gymnasium at <www.riemenschneider-gymnasium.de/2016/12/o2/auf-den-spuren-der -keilschrift $/>$ (last accessed 19 March 2020). 